\title{
Kalkınma İçin Bölgesel İşbirliği Teşkilatı Üyesi Ülkeler Arasında Turizmi Geliştirme İşbirliği
}

\author{
Ayşe ERKMEN
}

Öğr. Gör. Dr., Gaziantep Üniversitesi, aerkmen@gantep.edu.tr

\section{ÖZET}

Çalışmanın amacı 1964 yılında Türkiye, Pakistan ve İran arasında kurulan Kalkınma İçin Bölgesel İşbirliği Teşkilatı (RCD)'nın turizm konusundaki çalışmalarını araştırıp belirlemektir. Bu doğrultuda yapılan literatür araştırmaları sonucunda elde edilen bilgiler ele alınmıştır. RCD üyesi üç ülke turizm alanında faydalanılacak tarihi, kültürel ve coğrafi mirasa sahip ülkelerdir. Üç ülkenin çeşitli alanlarda turizmi gerçekleştirme potansiyelleri mevcuttur. Uluslararası turizm talebinde yaşanan artış ve turizmi geliştirmenin maliyetinin diğer alanlara göre düşük seviyede olması gelişmekte olan ülkeleri uluslararası turizmi geliştirmeye sevk etmiştir. 1960'larda RCD üyesi ülkelerin de bu düşünceden hareketle hem RCD bölgesi içinde turistik hareketliği artırma hem de bölge dışındaki turisti bölgeye çekme yönünde gayret sarf ettiği görülmektedir. 1964 yılında RCD'nin kurulmasıyla bölgede turizmi geliştirme ve yaygınlaştırma konusunun toplanan komitelerde, Planlama Teşkilatı ve Bakanlar Konseyi toplantılarında ayrıntılı olarak ele alındığı bir çalışma süreci başlatılmıştır. Ekim 1964'te Tahran'da gerçekleştirilen ilk Bakanlar Konseyi toplantısında üç ülkenin bir turizm anlaşması imzalaması ve karşılıklı vizelerin kaldırılması kararı alınmıştır. Bunda amacın bölgede kolayca seyahat edilmesini ve üç ülke halkının birbirine yakınlaşmasını sağlamak olduğu belirtilmiştir. Daha sonraki toplantılarda, üye ülkelerin karşılıklı turist büroları açması, diğer ülkelerden seyahat yazarlarının ve seyahat acentaları temsilcilerinin davet edilmesi, üç ülkenin yol ve trafik işaretlerinin BM kuralları ile uyumunun sağlanması gibi kararlar alınmıştır. Gümrük yasasının BM Sözleşmesine uygun hale getirilmesi, bagaj muayene kurallarının basitleştirilmesi, turizmi teşvik için fuarlar ve sergiler açılması, kültür olaylarına katılım ve turizm propagandası yapmak gibi uygulamalara gidilmesi çalışmaları başlatılmıştır. Bir ülkenin diğer iki ülkede yapmak istediği yatırımlar konusunda kolaylık sağlanması, turizm amaçlı yayınların ortak hazırlanması ve turizm alanında ortak yatırımlar yapılması gibi düzenlemelere gidilmiştir. Gençliği turistik gezilere teşvik çalışmaları yapılmıştır. Belli bir süre turizm konulu çalışmaların bölgede turizmi geliştirmek amacını taşıdığı, ancak daha sonraki süreçte bölge turizminin dişına çıkılmak ve bölgeyi dünya turizmine açmak için çalışmalar başlatıldığı görülmektedir. Bunun için tüm bölgenin turizm potansiyelinin belirlenmesi ve sahip olunan potansiyelin değerlendirilmesi için çalışmalar başlatılmıştır. 1970 yılına gelindiğinde, RCD sekretaryasının bölgeler arası esaslar kapsamında bir turizm araştırması yapılması için BM organlarından uygun olan birinden mali ve teknik yardım sağlama imkânlarını araştırması kararı alınmıştır. Bu şekilde, RCD kapsamında üç ülke arsında çalışmalar 1979 yılına kadar sürdürülmüştür. Çalışmada, RCD’nin Birinci ve İkinci Adalet Partisi Hükümetleri Dönemi turizm çalışmaları araştırılmıştır.

Anahtar kelimeler: RCD, Turizm, Türkiye, Pakistan, İran 


\title{
Cooperation Between the Regional Cooperation Organization for Development Member Countries to Develop Tourism
}

\begin{abstract}
The aim of the study is to investigate and determine the tourism works of the Regional Cooperation Organization for Development (RCD), which was established between Turkey, Pakistan and Iran in 1964. As a result of literature researches conducted in this direction, the information obtained was discussed. Three RCD member countries are the countries with historical, cultural and geographical heritage that can be utilized in the field of tourism. Three countries have the potential to realize tourism in various field. The increase in international tourism demand and the low cost of developing tourism compared to other fields encourages developing countries to develop international tourism. In the $1960 \mathrm{~s}$, it is seen that RCD member countries also made an effort to increase touristic activity within the RCD region and to attract tourists from outside the region. With the establishment of the RCD in 1964, the committees gathered on the issue of developing and expanding tourism in the region, a work process was initiated in which it was discussed in detail at the Planning Organization and the Council of Ministers meetings. At the first Council of Ministers meeting in Tehran in October 1964, it was decided that the three countries would sign a tourism agreement and abolish mutual visas. It was stated that the purpose of this meeting was to enable easy travel in the region and bring the people of the three countries closer to each other. In the following meetings, decisions such as the opening of tourist bureaus by member countries, inviting travel writers and representatives of travel agencies from other countries, ensuring that the road and traffic signs of the three countries would comply with the UN rules were taken. Implementation works such as bringing the customs law into compliance with the UN Convention, simplifying the baggage inspection rules, opening fairs and exhibitions to promote tourism, participation in cultural events and making tourism propaganda were initiated. Arrangements such as facilitating the investments that a country wants to make in the other two countries, joint preparation of publications for tourism purposes and joint investments in the field of tourism were made. Efforts were made to encourage young people to take touristic trips in the region. However, in the following process, it is seen that studies were initiated to go out of the region tourism and open the region to world tourism. For this, the studies to determine the tourism potential of the whole region and to evaluate the existing potential were initiated. By 1970, it was decided that the RCD secretariat should have investigated the possibilities of providing financial and technical assistance from a suitable one of the UN Members in order to conduct a tourism research within the scope of the regional plot principles. In this way, studies were carried out until 1979 between the three countries within the scope of the RCD. In the study, tourism studies of the RCD's First and Second Justice Party Governments Period were investigated.
\end{abstract}

Keywords: RCD, Tourism, Turkey, Pakistan, Iran

\section{GÍRIS}

Turizm, Latince "tornus” sözcügünden türetilmiştir. İngilizceye "tour” olarak geçmiş ve daire, iş veya eğlence amaçlı yapılan yer değiştirme faaliyeti anlamımda kullanılmaktadır. Türkçeye dönmek veya döndürmek anlamında dâhil olan "tur" kelimesi, dönme, hareket etme ve gezinti yapma anlamımda kazanmıştır. "Tur” başlama noktasına dönmek koşuluyla yapılan kısa veya

Year 5/ 2021, Volume-5, Issue-1 | WWW.ispecjournal.org 
uzun seyahat olarak tanımlanmaktadır (Akın, 2018b: 2- 13). Turizm kavramı 1994 yılında Bileşmiş Milletler (BM) ve "Dünya Turizm Örgütü” tarafından "insanların, eğlence, iş veya diğer amaçları doğrultusunda yaşamış oldukları yerin dışında başka bir yere gitmesi ve seyahat başlangıç süresini takip eden zaman içerisinde bir yılı geçmemek üzere gittikleri yerlerde kalmaları" olarak tanımlanmıştır (Köseoğlu, 2019: 6).

İnsanın var oluşundan günümüze kişiler sürekli ikamet ettikleri yerlerden çıkıp farklı yerlere seyahat yapmaktadır. Günümüzde turizm faaliyeti olarak adlandırdığımız bu seyahatler insanlar üzerinde hukuksal, sosyal, politik, ekonomik, kültürel v.b. alanlarda etki etme özelliğine sahiptir. Yapılan seyahatlerle faklı din dil, kültür ve etnik yapıya sahip insanların bir araya gelmesi sağlamaktadır (Akın, 2018a: 99) Seyyahlar farklı varış yerlerini ziyaret ederek tarihi, kültürel, coğrafi konularda yeni bilgiler edinebilmekte ve yeni deneyimler kazanabilmektedir. (Vatan, 2018: 605).

Turizm 20. yüzyılın başlarından başlayarak ulusların ve bölgelerin kalkınması için önemli bir endüstri alanı halini almıştır (Soyu, Karaçor, Altınok \& Fırat, 2017: 442). Bu nedenle turizm faaliyetleri bacasız sanayi olarak adlandırılmaktadır. Günümüzde turizmin önemi her geçen gün artarak devam etmektedir. Turizmin gelişmesine insanların çalışma koşullarının iyileşmesinin önemli oranda etki ettiği görülmektedir. Çalışan insanların fazla gelir elde etmesi, boş zamana sahip olması (yıllık izin v.b.) ulaşım alanlarındaki gelişmelerle seyahatin hızlı ve konforlu bir şekilde yapılabilmesi, iletişim alanında yaşanan gelişmeler ve bazı ülkelerin karşılıklı vizeleri kaldırma yoluna gitmesi insanları yoğun olarak turizm faaliyetini gerçekleştirmeye teşvik etmektedir (Erkmen \& Akın, 2018: 202). Türkiye'de turizmi geliştirmenin ilk adımlarının Osmanlı Devleti'nin son dönemlerinde atıldığı görülmektedir. Türkiye'de kuruluşundan itibaren az da olsa turizmi geliştirme yönünde çalışmalar başlatmıştır. 1960'lı yıllarla birlikte belirlenen turizm hedeflerine kalkınma planlarında yer verilmeye başlanmış, turizmin önemli olduğu bilinciyle hareket edilmiştir. Ancak araştırmalar Türkiye'de turizm sektörünün 1980'li yıllardan itibaren istenen düzeyde sonuçlar vermeye başladığını göstermektedir (Akın, 2020a: 129).

\section{1. 1960'lı Yıllara Kadar Türkiye'de Turizm}

Osmanlı Devletinde Sultan II Mahmut döneminde buharlı gemilerin alımına ve yapımına başlandığı için çağdaş anlamda turizme yönelik ilk adımın bu dönem atıldığını söyleyebiliriz. $\mathrm{Bu}$ süreçte seyahat imkânlarının gelişmesiyle Sultan Abdülaziz'in Avrupa gezisi yaptığı görülmektedir. Bu gezide Avrupa'da gördüklerinden etkilenen Sultan, İstanbul'da "Sergi-i Umumi-i Osmani” isimli fuarın açılmasını sağlamıştır (Özdemir, 2011: 90). Bu dönem İstanbul'da bir seyahat acentesi kurulması (Köseoğlu, 2019: 12), Paris-İstanbul arası demiryolunun kullanıma açılması, Pera Palace Oteli'nin kurulması, Wagon-Li firmasına ait "Orient Express" treninin Paris-İstanbul hattında seferler başlatması gibi gelişmeler yaşanmıştır (Bacaklıŏglu, 2017: 6; Çetin, 2018: 65; (Sarı Çallı, 2015: 18). Birinci Dünya Savaşı'nın başlamasının her alanda olduğu gibi bu alanı olumsuz yönde etkilediği görülmektedir.

Türkiye, tarihiyle, kültürel mirasıyla turizm potansiyeline sahip önemli ülkelerden biri olma özelliğine sahiptir (Çımat ve Bahar, 2003: 2). Ülkede, deniz, kum ve güneş turizminin yanı sıra sahip olduğu kaynakları kullanarak farklı turizm alanları yaratma potansiyeli mevcuttur (Akın, 2020b: 134). Türkiye Cumhuriyeti'nin kuruluş yıllarında, ülke içinde ve dışında birçok sorunla uğraşılmak durumunda kaldığ süreç yaşanmıştır. Bununla birlikte bu dönem turizmi geliştirmeye yönelik bazı adımların

Year 5/ 2021, Volume-5, Issue-1 | WWW.ispecjournal.org 
atıldığı da bilinmektedir.1923 yılında "Türk Seyyahin Cemiyeti”nin kurulması bu konuda atılan ilk adım olarak gösterilmektedir (Köseoğlu, 2019: 8-13). Kuruluşun adı 1930 yılında değiştirilmiş ve "Türkiye Turing ve Otomobil Kulübü" adını almıştır. Türkiye'nin ilk karayolu haritalarının ve ilk afişlerin basımının yapılması, ilk olarak turizm konulu incelemelerin ve ilk tercüman rehberlik sınavlarının yapılması bu kurum tarafından gerçekleştirilmiştir (Yıldız, 2011: 57-58). 1923'de "Milli Türk Seyahat Acenteliği Ziya ve Şükerası"nın kurulması (Sarı Çallı, 2015: 18-19). 1925 yılında “Türkiye Tayyare Cemiyeti”nin kurulması ve adının 1933 yılında “Türk Havayolları İşletme İdaresi” şeklinde değiştirilmesi gibi gelişmelerin yaşandığı bilinmektedir (Bacaklığlu, 2017: 6-7). 1934 yılında "İktisat Vekâleti Teşkilatı ve Vazifeleri Hakkında Kanun” kabul edilmiş (Yıldız, 2011: 58) ve böylece turizm bir kamu hizmeti halini almış ve 1937 yılına kadar "Ticaret Dairesi”ne bağlı kalmıştır. Şube'nin 1939 yılında “Turizm "Müdürlüğü” adını alarak Ticaret Vekâlet'ine bağlandığı görülmektedir. Yapılan bir kanuni düzenlemeyle 1949 yılında "Basın Yayın Turizm Genel Müdürlüğü "nün kurulduğu, 1953 yılından başlayarak özel sektörü turizme teşvik etme çalışmalarının önem kazandığı gibi gelişmeler bu alanda yapılanlardandır. "Basın Yayın ve Turizm Vekâleti" 1957 yılında kurulurken, 1960 yılında "Turizm Bakanlığı"nın kurulduğu ve 1963 yılında "Basın Yayın ve Turizm Vekâleti” nin adının “Turizm ve Tanıtma Bakanlığı” şeklinde değiştirildiği görülmektedir (Erkmen, 2019: 25-26; Dinçer \& Çetin, 2015). 1960'lı yıllarla birlikte ekonomide planlı döneme geçilince kalkınma planları içinde turizm konusuna da yer verilmeye başlanmıştır (Bacaklığlu, 2017: 7).

RCD' üyesi ülkelerden Pakistan'ın sahip olduğu coğrafyası, kültürel ve tarihi mirası ile turizmin gelişmesi için gereken potansiyele sahip bir ülke olduğu bilinmektedir. İran'da aynı şekilde tarihi, kültürel mirasa ve turizm alnında çeşitli aktivitelerin yapılabileceği potansiyele sahip olma özelliğine sahiptir.

Günümüzde uluslararası turizm talebinde artış yaşanması, turizmi geliştirmenin maliyetinin düşük olması gibi nedenlerle gelişmekte olan ülkelerin uluslararası turizm faaliyetlerine ilgi duyduğu bir süreç yaşanmaktadır (Akıncı ve Yüzbaşığlu, 2015: 46-47). Türkiye'nin 1960'larda turizmin ekonomik açıdan öneminin bilinciyle turizmi geliştirme çalışmalarını hızlandırmaya gayret gösterdiği görülmektedir. 1964 yılında kurulan RCD'nin üyesi üç ülke bu bilinçle, bölgelerinde ve uluslararası alanda turizmi geliştirme çalışmaları yürütmüşlerdir. RCD'nin bu yöndeki faaliyetleri turizmin geliştirilmesine katkı sağladığı için önem arz etmektedir.

Kuruluşun resmi adı "Regional Cooperation for Development" dir. İngilizce olan resmi adının kısaltması "RCD" dir (Sandalcılar, 2010: 49). Türkçe adı ise "Kalkınma İçin Bölgesel İşbirliği Teşkilatı'dır. Türkçe adının kısa yazılışı ise "KİBİ”dir. Bu çalışmada kaynak olarak faydalanılan Türkiye Cumhuriyeti Dışş̧leri Bakanlığı Arşivi'ndeki kaynaklarda "RCD" kullanıldı̆̆ için bu çalışmada da bu kısaltma kullanılmıştır.

Bu çalışmanın amacı 1964 yılında kurulan RCD’nin üyesi üç ülkenin turizmi geliştirmeye yönelik ortak çalışmalarını belirlemektir. Bu doğrultuda araştırma yapılmış ve elde edilen bilgilerle çalışma tamamlanmıştır. Çalışma, Birinci ve İkinci Adalet Partisi Hükümetleri dönemi ile sınırlandırılmıştır.

\subsection{RCD (Kalkınma İçin Bölgesel İşbirliği Teşkilatı /KİBİ)'nın Kuruluşu ve Teşkilatı}

RCD’yi kuracak olan üç ülke Pakistan, Türkiye ve İran ortak tarihi geçmişe ve kültürel mirasa sahip ülkelerdir (Öner, 1974:358). RCD’nin kurulması fikrini ilk ortaya atan devletin Pakistan

Year 5/ 2021, Volume-5, Issue-1 | WWW.ispecjournal.org 
olduğu görülmektedir. Pakistan bölge dışı ülkelere ihtiyaç duyulmasını önleyecek bir kültürel ve iktisadi örgütlenmeye gidilmesini talep etmiştir (Akdevelioğlu \& Kürkçüoğlu, 2009:804). Pakistan'ın talebi, ülkenin üye olarak yer aldığı CENTO'nun 1964 yılı Nisan ayında Washington'da yapılan toplantısı sırasında görüşülmüştür. Üç ülke devlet ve hükümet başkanları 21 Temmuz 1964'te İstanbul'da gerçekleştirdikleri zirve toplantısı sonunda RCD'yi kurduklarını açıklamışlardır. Açıklanan ortak bildiride, üç ülkenin mevcut olan işbirliğini her alanda daha da genişletmeyi ve geliştirmeyi amaçladıklarını ve bunun için gereken önlemlerin alınmasına ve ortak çalışmalar yapılmasına karar verdiklerini açıklamışlardır. $\mathrm{Bu}$ açıklamaya göre $\mathrm{RCD}$, bölge insanlarının kalkınma düzeylerini yükseltmek ve teknik, ekonomik ve kültürel alanlarda bölgesel işbirliğini sağlamayı amaçlamıştır (Uçarol, 2006: 896; Yeşilbursa, 2009:637; Quresh, 116 ).

RCD, Tahran'da üç üye ülkenin uzmanlarının yer aldığı bir genel sekreterliğe sahiptir (Ertürk, 2001: 265). Bu genel sekreterlik teşkilatın koordinasyonunu sağlamaktadır. RCD’nin başlıca organları aşağıdan yukarı doğru sıralandığında; çeşitli işbirliği sahalarında çalışmalar yürüten komiteler, planlama teşkilatı başkanlarının yer aldığ "Planlama Konseyi" ve üç ülke dışişleri bakanlarından müteşekkil “ Bakanlar Konseyi” oluşturmaktadır (Dışişleri Belleteni, Say1: 46, Belge:19, Temmuz 1968: 64- 65)

\subsection{RCD Ülkelerinde Turizm İşbirliği}

RCD kurulduktan sonra ilk bakanlar düzeyinde toplantısını 15-16 Ekim 1964 tarihleri arasında İran'ın başkenti Tahran'da gerçekleştirmiştir. Birinci Bakanlar Konseyi Toplantısı'ndan sonra yayınlanan ortak bildiride turizm konusuna da yer verilmiştir. Konsey, Bölgesel Planlama Komitesi'nin turizm konusundaki tavsiyelerini kabul ettiğini belirtmiştir. Böylece; üç ülkenin dışişleri bakanlarının üç ülke arasında bir turizm anlaşması imzalaması ve ikili olarak ülkeler arsındaki vizelerin kaldırılması anlaşması yapılmıştır. Türkiye ile Pakistan vize kaldırılması konusunda daha önce bir anlaşma yapmış olduğu için vize kaldırma konusunda Türkiye sadece İran ile bir anlaşma imzalamıştır. Yapılan anlaşmanın amacı; turist akışını sağlamak, üç ülke halkının birbirini yakından tanıması imkânını oluşturmak ve bölge dâhilinde kolayca seyahat edilmesi imkânı yaratmak olarak belirtilmiştir (Dışişleri Belleteni No: 1, Ekim 1964: 50-51).

Bakanlar Konseyi kararları doğrultusunda 10-14 Kasım 1964 tarihinde Ankara'da RCD Turizm Komitesi toplanmış ve turizm konusunda üst kurula sunmak üzere tavsiye kararları almıştır. Bu tavsiye kararları; RCD üyesi üç ülke arsında seyahati kolaylaştırmak için seyahat belgelerini ve gümrük formalitelerini basitleştirme, gümrük formalitelerinin basitleştirilmesi için RCD ülkelerinin her birinin diğer iki ülkeye "turist büroları" açması ve üç ülkenin "Milli Turizm İdareleri'nin diğer ülkelerden seyahat yazarlarını ve seyahat acenta temsilcilerini davet etmeleri kararı alınmıştır. İlaveten, yol ve trafik işaretlerinde ahengin sağlanması için Birleşmiş Milletler'in (BM) en son 'Yol İşaretleri Sözleşmesi'nin RCD ülkelerinin kabul etmesi ve üye üç ülkenin her birinin Milli Şoförlük ehliyetlerinin diğer iki ülkede de geçerli olması gerektiğgi belirtilmiştir. Seyahat ve yayın ajanlarının dış ülkelerden RCD ülkelerine turist akımını hızlandırmak için üç ülke tarafından kullanılması ve bu konuda Türkiye'nin gelecek toplantıya kadar bir rapor hazırlaması benimsenmiştir (Dışişleri Belleteni No: 1, Ekim 1964: 53-54).

1964 yılının sonbaharında başlayan RCD komite çalışmaları ile hazırlanan tavsiye mahiyetindeki raporlar Pakistan'ın yeni başkenti İslamabad'da 13-16 Mart 1965 tarihleri arasında toplanan "RCD Bölgesel Planlama Konseyi" tarafından incelendikten sonra bir rapor

Year 5/ 2021, Volume-5, Issue-1 | WWW.ispecjournal.org 
haline getirilmiştir. $\mathrm{Bu}$ rapor RCD Bakanlar Konseyi tarafından 18-19 Mart 1965'de İslamabad'da görüşülerek kabul edilmiş ve RCD ortak bildirisi olarak yayınlanmıştır. Ortak bildiride turizm konusuna da yer verilmiştir (Dışişleri Belleteni, Sayı: 6, Mart 1965: 7). Konsey'de RCD bölgesinde yapılacak seyahatleri kolaylaştırmak için bir "RCD Kimlik Kartının”nın kabul edilmesi, Gümrük Yasasının “1954 (New -York) BM’nin gümrük kolaylıkları sözleşmesine uygun hale getirilmesi için gereken düzenlemelerin yapılması benimsenmiştir. İlaveten, turistlere ait taşıtların, RCD ülkelerine giriş ve çıkışlarında kolaylıklar sağlanması amacıyla "1954 (New-York) özel kara taşıt araçlarının geçici ithaline dair BM sözleşmesi" kapsamında düzenlemeler yapılması kararları alınmıştır. "Milli ehliyetler vizelerin ilgası anlaşmalarında öngörülen surelerin bütün bölge ülkelerinde geçerli olmaları" ve "RCD ülkeleri vatandaşlarının vizelerin ilgası anlaşmalarında öngörülen sureler için yabancılar bakımından gerekli tescil işlerine tabi tutulmamaları" hedef olarak belirlenmiştir. Bunlara ek olarak; bagaj muayene kurallarının basit hale getirilmesi, RCD bölgesi haricinde ortak bürolar açılması için gereken çalışmaların yapılması benimsenmiştir. Yukarıda yer verdiğimiz, komite kararlarından olan RCD ülkelerinin karşılıklı turist büroları açması ve üç ülkenin "milli turizm teşkilatlarının kendi hesaplarına diğer iki ülkenin seyahat yazarlarını ve seyahat acentalarını" bölge içi turizmin geliştirilmesi için davet etmeleri önerileri Bakanlar Konseyi'nde kabul edilmiş ve uygulanması için çalışmaların başlatılması istenmiştir. Bunlara ilaveten "Turizm Komitesi”nin turizmi teşvik için fuar ve sergi açmak, kültür olaylarına katılım ve turizm propagandası yapmak gibi çalışmalarında "Kültürel İşbirliği ve Tanıtma Komiteleri” ile işbirliği halinde çalışması faydalı görülmüştür. Ayrıca RCD ülkelerinin turizm komitelerine turist rehberleri, turizmi teşvik personel ve otel personeli yetiştirilecek birkaç kurumun kurulması konusunda ayrıntılı etütler yapması önerilmiştir. Uygun görülen turizm projeleri konusunda RCD ülkelerinden birinin diğer iki ülkede yapmak istediği yatırımlarda ve RCD ülkelerinin vatandaşlarının böyle projelerde istihdamı konusunda ülkelerin milli mevzuatları çerçevesinde kolaylık sağlanması istenmiştir. "Milli turizm teşkilatlarının mevcut turizm anlaşmasının" uygulamaya konulması aşamasında fikir teatisinde bulunmaları ve RCD sekretaryasından da bu konuda faydalanılması faydalı görülmüştür. İkinci Bakanlar Konseyi toplantısında Türkiye'nin turizm alanında bazı konularda raporlar hazırlaması istenmiştir. Bunlara ek olarak "turist gönderen ülkelerden bölgeye her yıl 15 seyahat yazarının davet edilmesi," "bir rehber, bir bölge haritası, bir önemli olaylar takvimi, afişler ve mümkün olduğu takdirde bir film gibi turistik propaganda malzemesinin ortak olarak hazırlanması ve yayımı için gerekli tedbirlerin alınması" kararı alınmıştır. Ayrıca "reklam ve seyahat acentalarının hariçten bölgeye turist akımını teşvik amacıyla ortaklaşa istihdam edilmesi," yoluna gidilmiştir (Dışişleri Belleteni, Sayı:6, Mart 1965: 12-13).

RCD'nin kuruluşunun birinci y1ldönümü olan 21 Temmuz 1965 günü Türkiye Cumhuriyeti Cumhurbaşkanı Cemal Gürsel, Başbakan Suat Hayri Ürgüplü ve Dışişleri Bakanı Hasan Işık birere kutlama mesajı yayınlamışlardır. Başbakan’ın mesajında; “...Bugün, Türkiye, İran ve Pakistan arasında yakın bir işbirliği kurulması fikrinin gerçek temellere bağlandığı günün birinci yıldönümünü kutluyoruz. Gecen yıl bugün, üç devlet başkanı ve başbakanları yüzyıllardır üç ülke halkı arasında süregelen kardeşlik ve kültür birliği duyguları üzerine ekonomik yaklaşmanın çatısını kurmuşlardır..."sözlerine yer vermiştir (Dışişleri Belleteni, Say1: 10, Belge: 10, Temmuz 1965:33; Dışişleri Belleteni Sayı: 10, Belge: 11, Temmuz 1965: 33-34; Dışişleri Belleteni Sayı: 10, Belge: 13, Temmuz 1965: 35-38).

Bakanlar Konseyi üçüncü toplantısını 21-23 Temmuz 1965 tarihleri arasında Ankara'da gerçekleştirmiştir. RCD’ye üye üç ülkenin dışişleri bakanlarının başkanlıklarında yapılan toplantı sonunda yayınlanan ortak bildiride turizm konusuna da yer verilmişsir (Dışişleri

Year 5/ 2021, Volume-5, Issue-1 | WwW.ispecjournal.org 
Belleteni, Sayı: 10, Temmuz 1965:6). Bakanlar Konseyi, turizm konusunda, üç ülke arasında bir turizm anlaşması imzalandığı ve vizelerin kaldırıldığını belirtmişler ve bundan çok memnun olduklarını ifade etmişlerdir. Toplantıda turizm konusunda; RCD ülkeleri arsında turistik faaliyetlerin artırılmasını sağlamak amacıyla "pasaportlar yeni turist kartlarının ikamesine karar verildiği," yayınların ortak hazırlanması ve turizm alanında ortak yatırımlar yapılması gibi kararlar alındığı kaydedilmiştir. Konsey tanıtma başlıklı raporu içinde de turizme yer vermiştir. Bu başlık altında Türkiye, İran ve Pakistan'ın dışarda bulunan tanıtma temsilciliklerinin turizm ve tanıtma konularında işbirliği içinde çalışmaları öngörülmüştür (Dışişleri Belleteni, Sayı: 10, Belge: 14, Temmuz 1965: 41).

Üç RCD ülkesi arasında yapılacak dördüncü Bakanlar Konseyi toplantısı öncesi RCD’nin 1966 yılının ilk “Teknik İşbirliği Programı” İslamabad'da 1-2 Şubatta toplanmıştır. Arkasından RCD Bakanlar Konseyi dördüncü toplantısını 3-4 Şubat 1966 tarihleri arasında İslamabad'da gerçekleştirmiş ve Teknik İşbirliği Programı'nda belirlenen rapor burada onaylamıştır (Dışişleri Belleteni, Sayı: 17 Şubat 1966: 7, 53). RCD Bakanlar Konseyi'nin gelenek halinde her konsey toplantısı sonunda sunduğu ortak bildirilerden dördüncü toplantı sonrası yayınlananı tespit edilememiştir.

RCD'nin bazı komite toplantıları Nisan 1966'da Ankara'da toplanırken RCD Turizm Komitesi 18 Nisan 1966 tarihinde dördüncü toplantısını Pakistan'ın Dakka şehrinde gerçekleştirilmiştir. Toplantıda turizm alanında belirlenen hedefler gözden geçirilerek Bakanlar Konseyi'nde görüşülecek hale getirilmeye çalışılmıştır (Dışişleri Belleteni, Sayı: 19, Nisan 1966: 6, 19).

RCD Bakanlar Konseyi beşinci toplantısı Tahran'da 20-21 Mayıs 1966 tarihleri arasında gerçekleştirilmiştir. Konsey toplantı sonunda yayınladığı ortak bildiride RCD kapsamında belirlenen hedefleri gerçekleştirmek için üç üye ülkenin kararlı olduğunu vurgulamıştır. Ortak bildiride turizm konusuna da yer verilmiştir (Dışişleri Belleteni, Sayı: 20, Mayıs 1966: 47-48).

RCD ortak bildirisinde, üç üye ülkenin hükümetinin bölge içinde turist akışının teşvik edilmesi, turistik amaçlı tesisler açılması konusunda gerekenlerin yapılmakta olduğu belirtilmiştir. RCD Ticaret ve Sanayi Odasının üç ülkenin milli turizm teşkilatlarıyla işbirliği içinde çalışmasına karar verildiği ifade edilmiştir. Ayrıca RCD ülkelerindeki gençler arasında turizmin geliştirilmesi amacıyla bazı önlemlerin alınmasının hedeflendiği görülmektedir. $\mathrm{Bu}$ hedefler arasında gençlerin tarihi eserleri ve müzeleri ücretsiz gezebilmesinin sağlanması, gençlik gruplarına misafirhanelerin açılması ve gençlere yönelik seyahat ücretlerinde indirim yapılması gibi genç kuşağı turizme teşvik etmeye yönelik kararlara yer verilmiştir (Dışişleri Belleteni, Sayı: 20, Belge: 13, Mayıs 1966: 78-82).

RCD Planlama Konseyi altıncı toplantısını 21 Ocak 1967'de Devlet Bakanı Kamil Ocak'ın başkanlığında Ankara'da gerçekleştirmiştir (Dışişleri Belleteni, Sayı: 28, Belge: 18, Ocak 1967: 28). RCD Bakanlar Konseyi altınc1 toplantıs1 ise 22. 23 Ocak 1967'de Ankara'nın ev sahipliğinde ve Dişişleri Bakanı Çağlayangil 'in başkanlığında toplanmıştır (Dışişleri Belleteni, Sayı: 28, Ocak 1967: 38). Toplantı, Cumhurbaşkanı Cevdet Sunay'ın mesajının okunması ile açılmıştır. Sunay mesajında, üç RCD ülkesinden kardeş ülkeler diye söz etmiş ve RCD'nin edindiği gayelerin üç ülkenin istikbali ve istiklali için önemli olduğu vurgusunu yapmıştır (BCA, 30-1-0-0/40-326-22, 23.01.1967, Ek: B, Sayı:1-2). Çağlayangil yaptığ konuşmada, RCD üyesi ülkelerin eşsiz tarihi ve doğal zenginliklere sahip olduklarının belirlendiğini ve bu özellikleri nedeniyle RCD Turizm Komitesine o güne kadar gerektiği gibi işlenememiş bir sahanın işlemek üzere verildiğini belirtmiştir. Bakan, turizmin modern manada gelişebilmesi için belli bir yaşam seviyesine erişilmesi gerektiğini ifade etmiştir.

Year 5/ 2021, Volume-5, Issue-1 | WWW.ispecjournal.org 
Bakan bununla birlikte bu konuda RCD’nin ilk adımı atmasının ve üç ülke vatandaşlarının birinden diğerine serbest bir şekilde gidebilmelerini sağlamanın bir zorunluluk olduğunu bildirmiştir. Üç ülke hükümetlerinin bu yönde alacakları kararların turizm ve hizmet sektörünü ekonomik anlamda da geliştireceğinin altını çizmiştir. Bakanın konuşmasında, turizmin modern anlamda gelişmesinin hem ekonomik hem de kültürel olarak insanların belli bir gelişmişlik seviyesine erişmesi ile mümkün olduğunu vurguladığı görülmektedir. Söz konusu bölgede ise henüz bu seviyeye ulaşılamadığı ancak bunun ilk adımlarının atılmaya çalışıldığı anlaşılmaktadır (Dışişleri Belleteni, Sayı: 28, Belge: 22, Ocak 1967: 80-81). Altıncı Bakanlar Konseyi toplantısı arkasından yayınlanan ortak bildiride turizm konusunda bölge içinde ve bölgeler arsında turizmi teşvik amacıyla üç ülkenin hükümetlerinin gereken düzenlemeleri yapmakta olduğu, gençlik turizminin gelişmesine yönelik yapılan çalışmaların umut verici olduğu bildirilmiştir (Dışişleri Belleteni, Sayı: 28, Belge: 23, Ocak 1967: 89, 91).

10-11 Ağustos 1967 tarihinde Pakistan'ın başkenti İslamabad'da RCD yedinci bakanlar konseyini toplamıştır. Toplantı sonunda yayınlanan ortak bildiride turizm konusuna kısaca değinilmiştir. Üç ülke hükümetlerinin bölge dâhilinde turizmi geliştirmek için çalışmalarını sürdürdüğü, RCD karayolları broşürünün yayınlandığı, bölgede gençlerin yapacağı turistik gezilerin geliştirilmesi için hazırlıkların yapılmaya başlandığı beyan edilmiştir. Ayrıca RCD'nin ilgili organlarına bölge dışından üye ülkelere grup seyahatlerinin artırılması için çalışmaları önerilmiştir. Bu toplantıda bölge içi turizmi geliştirmek için özel bir plan üzerinde durulduğu da belirtilmiştir (Dışişleri Belleteni, Say1: 35, Belge:2, Ağustos 1967:34, 39).

4 Kasım 1967 tarihinde İran'ın Başkenti Tahran'da RCD çalışma grubu toplantısı yapılmıştır. Bu toplantıya o dönem Türkiye'yi temsilen Devlet Planlama Teşkilatı Müsteşarı olarak görev yapan Turgut Özal başkanlığında bir heyet katılmıştır (BCA, 30-18-1-2/212-7910/03.11.1967/Ek:105/Say1:1).

RCD’nin Bakanlar Konseyi’nin sekizinci toplantısı 14-15 Nisan 1968 tarihleri arasında Tahran'da gerçekleştirilmiştir. Türkiye adına Dışişleri Bakanı İhsan Sabri Çağlayangil'in başkanlığında bir heyet katılmıştır. Toplantı sonunda açıklanan ortak bildiride her alanda olduğu gibi (tarım, su kaynaklarının geliştirilmesi, bankacılık, sağlık ve kadınlar arası işbirliği) turizm alanında da çalışmaların ilerlediği açıklaması yapılmıştır. Bu toplantıda RCD'nin alanını genişletecek şekilde "RCD Hukuk Birliği”" ve "RCD Parlamenterler Birliğiı"nin kurulması için çalışmalar yapıldığı ve bunun memnuniyet verici düzeyde olduğu ifade edilmiştir (Dışişleri Belleteni, Sayı: 43, Belge: 22, Nisan 1968: 76, 83).

RCD’nin kuruluşunun dördüncü yıldönümünde üç üye ülkenin devlet ve hükümet yetkilileri tarafından karşılıklı kutlama mesajlar yayınlanmıştır (Dışişleri Belleteni, Sayı: 46, Temmuz 1968: 24).

1968 yılının Temmuz sonu ile Ağustos başında Tahran'da RCD üyesi üç ülkede turizmin geliştirilmesi konulu bir experler (uzmanlar) toplantısı yapılması planlanmıştır. Bu toplantıya Türkiye Hükümetini temsilen Devlet Planlama Teşkilatı turizm sektörü sorumlusu Tunay Akoğlu Başkanlığında bir heyet gönderilmiştir (30-18-1-2/224-63-9/14.08.1968/Ek:10538/Say1:1).

RCD devlet ve hükümet başkanlarının katıldığı birinci zirve toplantısı 21 Temmuz 1964'te İstanbul'da gerçekleştirilmişti. İkinci zirve toplantısı 21-25 Aralık 1968 tarihleri arasında Pakistan'ın şehirlerinden Karaçi'de toplanmıştır (Dışişleri Belleteni, Sayı: 51, Aralık 1968: 6).

4-6 Aralık 1968 tarihinde Ankara'da toplanan dokuzuncu RCD Bakanlar Konseyi toplantısı Cumhur Başkanı Cevdet Sunay’ın mesajının okunması ile açılmıştır (Dışişleri Belleteni, Sayı:

Year 5/ 2021, Volume-5, Issue-1 | WWW.ispecjournal.org 
51, Aralık 1968: 13). Açılış oturumunda Dışişleri Bakanı Çağlayangil bir konuşma yapmış ve konuşmasında turizme de değinmiştir. Turizmin söz konusu dönem Türkiye'de önem kazandığını belirtmiştir. Pakistan ve İran'da da turizmi teşvik için gereken imkânların olduğunu ifade eden. Bakan kendine has özellikleri olan bu imkânların Türkiye'de olduğu gibi İran ve Pakistan'da da gelir kaynağı haline getirilebileceğine inandığını ifade etmiştir. Bakan ayrıca kardeş olarak söz ettiği bu iki ülkenin turizm alanında gelişme sağlaması için Türkiye'nin bu alanda verimli bir işbirliği yapmaya hazır olduğunu bildirmiştir. Bununla birlikte turizm sektörünün sanayi sektöründen farklı olarak kendine has özellikleri olduğunu belirten Bakan, bu alandaki problemlerin realist (gerçekçi) bir yaklaşımla çözülmesi gerektiğini ifade etmiştir. Bakan üç ülke arsında turizmin geliştirilmesi için yapılmakta olan konsey toplantısını bir hamle olarak görmeyi arzu ettiğini de ifade etmiştir. Bakan Çağlayangil, RCD kapsamında üç ülkenin yapmakta olduğu alt yapı çalışmalarının, kara ve demiryolu ile liman ve denizcilik projelerinin de turizmi teşvik edeceği ve bölge içi turizmi artıracağı öngörüsünde bulunmuştur (Dışişleri Belleteni, Sayı: 51, Belge: 4, Aralık 1968: 4245). Dokuzuncu Konsey toplantısı sonunda açıklanan ortak bildiride turizm konusunda, üye ülkelerin milli turizm kuruluşlarının "RCD ortak turistik broşürleri ve karayolu haritası" bastıkları ve bölge içi ve bölgeler arası turizmin gelişmesi için RCD üyesi üç ülkenin gayretle çalıştıkları ifade edilmiştir (Dışişleri Belleteni, Sayı: 51, Belge: 5, Aralık 1968: 61).

29 Nisan 1969 tarihinde RCD Ticaret Komitesi Ankara'da toplanmış ve diğer ticari konularla birlikte turizm konusunu da ele almıştır (Dışişleri Belleteni, Sayı: 55, Nisan 1969: 31). RCD Bölgesel Planlama Konseyi ise 22-23 Haziran 1969 tarihleri arasında Pakistan'ın Ravalpindi şehrinde toplanarak Onuncu Bakanlar Konseyi toplantısına sunacağı raporu hazırlamıştır (Dışişleri Belleteni, Sayı: 57, Haziran 1969: 26).

RCD’nin Bakanlar Konseyi toplantılarından onuncusu 25-26 Haziran 1969 tarihleri arasında İslamabad'da toplanmıştır. Toplantı, Pakistan Cumhurbaşkanlığı kabine üyelerinden Amiral S. M. Ahsan'ın başkanlığında yapılmıştır. Türkiye adına giden heyete Dışişleri Bakanı Çağlayangil başkanlık ederken, İran heyeti İran Dışişleri Bakanı Ardeşir Zahedi, başkanlığında toplantıya katılmışlardır. Toplantı sonunda yayınlanan ortak bildiride turizm konusuna kısaca yer verilmiştir. Turizmin bölge içinde ve bölge dışında geliştirilmesinin sosyal ve ekonomik açıdan önemli olduğu vurgulanmıştır. Konsey, üç RCD üyesi ülkenin turizm teşkilatı başkanlarının 1969 yılının eylül ayında bir araya gelerek turizmin bölge içinde ve bölge dışında geliştirilmesi için yapılacakları ve bu potansiyelin ne olduğunu belirlemelerini ve bu konuda bir çalışma programı hazırlamalarını istemiştir (Dışişleri Belleteni, Say1: 57, Belge: 11, Haziran 1969: 57,71).

Bakanalar Konseyi'nin on birinci toplantısı Tahran'da gerçekleştirilmiştir. 27-28 Aralık 1969 tarihleri arasında gerçekleştirilen toplantıya İran Dışişleri Bakanı Ardeshir Zahedin ev sahipliği yapmıştır. Türk heyete Dışişleri Bakanı Çağlayangil, Pakistanlı heyete Tarım ve Çalışma Bakanı Mahmoud Haroon, başkanlık etmişlerdir. Yayınlanan ortak bildiride turizmden çok kısa söz edilmiştir. Konseyin onuncu toplantısında aldığı karar gereği üç üye ülkenin turizm teşkilatı temsilcilerinin 22-24 Ekim 1969 tarihleri arasında Tahran'da bir toplantı yaptıkları ve bu toplantıda turizm konusunda yapılması gerekenler konusunda bir rapor hazırladıkları belirtilmiştir. Bu raporu RCD üyesi ülkelerin hükümetlerinin incelemekte olduğu ifade edilmiştir (Dışişleri Belleteni, Sayı: 63, Belge: 19, Aralık 1969: 89, 92).

RCD Bakanlar Konseyi 4 Temmuz 1970 tarihinde Bursa'da on ikinci toplantısını gerçekleştirmiştir. Toplantıya Dışişleri Bakanı Çağlayangil ev sahipliği yapmıştır. Toplantıda Pakistan heyetine Ticaret Bakanı Ahsanul Haque ve İran heyetine Dışişleri Bakanı Ardeshir Zahedi başkanlık etmişlerdir. Toplantı Türkiye Cumhurbaşkanı Cevdet Sunay ve Başbakan

Year 5/ 2021, Volume-5, Issue-1 | WwW.ispecjournal.org 
Demirel'in gönderdikleri mesajların okunmasıyla açılmıştır. Toplantı sonunda yayınlana ortak bildiride Turizm konusuna da yer verilmiştir. Konsey on birinci konsey toplantısı kararı doğrultusunda Ekim 1969'da Tahran'da devletlerin turizm teşkilatı başkanları tarafından turizm konulu bir toplantı yapıldığını ve toplantıda bir rapor hazırlandığını belirtmiştir. Raporda belirtilen öngörüleri uygulamaya koymak için bir program taslağı hazırlandığ edilmiştir. Konsey ayrıca üç ülke milli turizm teşkilatları bakanlarının tüm bölgenin milletlerarası turizm potansiyelinin değerlendirilmesi amacıyla gereken çalışmaları yapmalarının istendiğini bildirmiştir. RCD sekretaryasının da bölgeler arsısı esaslar kapsamında bir turizm araştırması yapması için BM organlarından uygun olan birinden mali ve teknik yardım sağlama imkânlarını araştırmasının kararlaştırıldığı beyan edilmiştir (Dışişleri Belleteni, Sayı: 70, Temmuz 1970: 11; Dışişleri Belleteni, Sayı: 70, Belge: 4, Temmuz 1970: 39, 42). Birinci ve İkinci Adalet Partisi Hükümetleri döneminde RCD Bakanlar Konseyi toplantılarının Temmuz 1970’ten sonra yapılanları tespit edilememiştir. Bu toplantıların gerçekleştirilemediği ihtimal dâhilindedir.

\section{SONUÇ}

1964 y1lında, Türkiye, İran ve Pakistan'ın ortaklaşa kurduğu RCD (Kalkınmak İçin Bölgesel İşbirliği Teşkilatı), İran'ın başkenti Tahran'da teşkilatın koordinasyonunu sağlayacak bir genel sekreterliğe sahiptir. Kurumun başlıca organlarını Bakanlar Konseyi, Planlama Konseyi ve çeşitli iş birliği sahalarında çalışmalar yapan komiteler oluşturmaktadır. Turizm konusunda çalışmalar yapan bir Turizm Komitesi de organlar içinde yerini almış ve çalışmalar yürütmüştür.

RCD, 1964 yılında kurulduktan sonra Tahran'da gerçekleştirdiği ilk Bakanlar Konseyi toplantısında turizm konusunda üç ülke arsında vizelerin kaldırılması ve bir turizm anlaşması yapılması gibi kararlar almıştır. Teşkilat turizm alanında amacını üç ülke halkının yakınlaşmasını ve turist akışını sağlamak olarak belirtilmiştir. Kasım 1964'te Ankara'da toplanan Turizm Komitesi, RCD üyesi ülkeler arasında seyahati kolaylaştırmak amaciyla seyahat belgelerini ve gümrük formalitelerini basitleştirme, üç ülkede karş1lıklı turist büroları açma, her bir ülkenin diğer iki ülkede turist büroları açması, diğer ülkelerden seyahat yazarlarını ve seyahat acenta temsilcililerini davet etme gibi kararlar almıştır. Yol ve trafik 1şıklarının BM'nin uygulanmakta olan yol işaretleri sözleşmesine uygun hale getirilmesi, üç ülkenin karşılıklı milli şoförlük ehliyetlerinin geçerli sayılması, turizm akışını hızlandırmak için seyahat ve yayın ajanlarından faydalanılması gibi düzenlemelere gidilmiştir. Mart 1965'de İslamabad'da toplanan Bakanlar Konseyi'nde gümrük yasasının 1954 BM turizm sözleşmesine uygun hale getirilmesi hedeflenmiştir. RCD Kimlik Kartı"nın kabul edilmesi, turistlere ait taşıtların, RCD ülkelerine giriş ve çıkışlarında kolaylık sağlamak için BM'nin bu konu ile ilgili 1954 tarihli sözleşmesi kapsamında düzenlemeler yapılması, bagaj muayene kurallarının basitleştirilmesi gibi kararlar onaylanmıştır. Turizmi teşvik amaçlı sergilerin ve fuarların açılması, kültür programlarına katılım, RCD ülkelerinden birinin diğerinde yatırım yapma isteği karşısında kolaylıklar sağlanması, milli turizm teşkilatlarının mevcut turizm anlaşmasının uygulamaya konulması aşamasında karşılıklı fikir teatisinde bulunmaları gibi uygulamalar benimsenmiştir. Bir rehber, bir bölge haritası, bir önemli olaylar takvimi, afişler ve film gibi turistik propaganda malzemesinin ortak olarak hazırlanması, reklam ve seyahat acentalarının dışarıdan bölgeye turist akımını teşvik amacıyla ortaklaşa istihdam edilmesi kararlarının uygulanması yoluna gidilmiştir. Temmuz 1965 'de Ankara'da toplanan üçüncü konsey toplantısında ise Türkiye, İran ve Pakistan'ın dişarıda bulunan tanıtma temsilciliklerinin turizm ve tanıtma konularında işbirliği içinde çalışmaları öngörülmüştür.

Year 5/ 2021, Volume-5, Issue-1 | WWW.ispecjournal.org 
Konsey, Mayıs 1966'da Tahran'daki beşinci toplantısında alınan kararlar doğrultusunda bölgede turist akımının sağlanması ve turistik amaçlı tesisler açılması konusunda gerekenlerin yapılmakta olduğunu belirtmiştir. Toplantıda ayrıca gençliği turistik faaliyetlere teşvik için tarihi eserleri, müzeleri ücretsiz gezebilmelerinin sağlanması, gençlik gruplarına misafirhanelerin açılması ve seyahat ücretlerinde indirime gidilmesi kararları alınmıştır. Konsey 1968 yılında Tahran'da gerçekleştirilen sekizinci toplantısında turizm alanındaki çalışmaların istenen şekilde ilerlediğini belirtmiştir. Konsey 1969 yılındaki onuncu toplantısında turizmin hem bölge içinde hem de bölge dışında geliştirilmesinin sosyal ve ekonomik açıdan önemli olduğu üzerinde durmuş ve bu yönde kararlar almıştır.

1970 yılında Bursa'da gerçekleştirilen on ikinci Bakanlar Konseyi toplantısında tüm RCD bölgesinin milletler arası turizm potansiyelinin belirlemesi ve Kurumun sekretaryasının bölgeler arsısı esaslar kapsamında bir turizm araştırması yapması için BM organlarından uygun olan birinden mali ve teknik yardım sağlama imkânlarını araştırması kararı almıştır. Böylece RCD bölge içinde turizmi geliştirmenin yanı sıra bölgeyi dünya turizmine açma çalışmalarını da hızlandırmıştır. RCD bu şekilde bölgede turizmi geliştirmeye yönelik çalışmalarını sürdürmüştür.

\section{KAYNAKÇA}

\section{Arşiv Kaynakları}

\section{Cumhurbaşkanlığı Devlet Arşivleri Genel Müdürlüğü Cumhuriyet Arşivi (BCA).}

BCA, Kararlar Daire Başkanlığ1, 30-18-1-2/212-79-10/03.11.1967/Ek:105/Sayı:1.

BCA Kararlar Daire Başkanlığı 30-18-1-2/224-63-9/14.08.1968/Ek:105-38/Sayı:1.

BCA, Başbakanlık Özel Kalem Müdürlüğü, 30-1-0-0/40-326-22, 23.01.1967, Ek: B, Say1:1-2.

\section{Resmi Belgeler}

Dışişleri Belleteni (Türkiye Cumhuriyeti Dışişleri Bakanlığı, Ankara), No: 1, Ekim 1964.

Dışişleri Belleteni (Türkiye Cumhuriyeti Dışişleri Bakanlığı, Ankara), Sayı:6, Mart 1965.

Dışişleri Belleteni (Türkiye Cumhuriyeti Dışişleri Bakanlığı, Ankara), Sayı: 10, Temmuz 1965.

Dışişleri Belleteni (Türkiye Cumhuriyeti Dışişleri Bakanlığı, Ankara), Sayı: 10, Belge: 10, Temmuz 1965.

Dışişleri Belleteni (Türkiye Cumhuriyeti Dışişleri Bakanlığı, Ankara), Sayı: 10, Belge: 11, Temmuz 1965.

Dışişleri Belleteni (Türkiye Cumhuriyeti Dışişleri Bakanlığı, Ankara), Sayı: 10, Belge: 13, Temmuz 1965.

Dışişleri Belleteni (Türkiye Cumhuriyeti Dışişleri Bakanlığı, Ankara), Sayı: 10, Belge: 14, Temmuz 1965.

Dışişleri Belleteni (Türkiye Cumhuriyeti Dışişleri Bakanlığı, Ankara), Sayı: 17 Şubat 1966.

(Dışişleri Belleteni (Türkiye Cumhuriyeti Dışişleri Bakanlığı, Ankara), Sayı: 19, Nisan 1966.

Dışişleri Belleteni (Türkiye Cumhuriyeti Dışişleri Bakanlığı, Ankara), Sayı: 20, Mayıs $1966 .$. 
Dışişleri Belleteni (Türkiye Cumhuriyeti Dışişleri Bakanlığı, Ankara), Sayı: 20, Belge: 13, Mayis 1966.

Dışişleri Belleteni(Türkiye Cumhuriyeti Dışişleri Bakanlığı, Ankara), Sayı: 28, Belge: 18, Ocak 1967.

Dışişleri Belleteni (Türkiye Cumhuriyeti Dışişleri Bakanlığı, Ankara), Sayı: 28, Belge: 22, Ocak 1967.

Dışişleri Belleteni (Türkiye Cumhuriyeti Dışişleri Bakanlığı, Ankara), Sayı: 28, Belge: 23, Ocak 1967.

Dışişleri Belleteni (Türkiye Cumhuriyeti Dışişleri Bakanlığı, Ankara), Sayı: 35, Belge: 2, A ğustos 1967.

Dışişleri Belleteni (Türkiye Cumhuriyeti Dışişleri Bakanlığı, Ankara), Sayı: 43, Belge: 22, Nisan 1968.

Dışişleri Belleteni (Türkiye Cumhuriyeti Dışişleri Bakanlığı, Ankara), Sayı: 51, Aralık 1968.

Dışişleri Belleteni (Türkiye Cumhuriyeti Dışsişleri Bakanlığı, Ankara), Sayı: 51, Belge: 4, Aralık 1968.

Dışişleri Belleteni (Türkiye Cumhuriyeti Dışişleri Bakanlığı, Ankara), Sayı: 46, Temmuz 1968.

Dışişleri Belleteni (Türkiye Cumhuriyeti Dışişleri Bakanlığı, Ankara), Sayı: 51, Belge: 5, Aralık 1968.

Dışişleri Belleteni (Türkiye Cumhuriyeti Dışişleri Bakanlığı, Ankara), Sayı: 55, Nisan 1969.

Dışişleri Belleteni (Türkiye Cumhuriyeti Dışişleri Bakanlığı, Ankara), Sayı: 57, Haziran 1969.

Dışişleri Belleteni (Türkiye Cumhuriyeti Dışişleri Bakanlığı, Ankara), Sayı: 57, Belge: 11, Haziran 1969.

Dışişleri Belleteni (Türkiye Cumhuriyeti Dışişleri Bakanlığı, Ankara), Sayı: 63, Belge: 19, Aralık 1969.

Dışişleri Belleteni (Türkiye Cumhuriyeti Dışişleri Bakanlığı, Ankara), Sayı: 70, Temmuz 1970.

Dışişleri Belleteni (Türkiye Cumhuriyeti Dışişleri Bakanlığı, Ankara), Sayı: 70, Belge: 4, Temmuz 1970.

Dışişleri Belleteni (Türkiye Cumhuriyeti Dışişleri Bakanlığı, Ankara), Sayı: 46, Belge: 19, Temmuz 1968.

\section{Kitaplar ve Makaleler}

Akdevelioğlu, A. \& Kürkçüoğlu, Ö. (2009). Orta Doğu'yla ilişkiler: İran ile ilişkiler. Türk Diş Politikası: Kurtuluş Savaşından Bugüne Olgular, Belgeler, Yorumlar (1919-1980), Baskın Oran (Ed.), Cilt: 1, (784-807), İletişim Yayınları, İstanbul.

Akın, A. (2020a). 2011 genel seçim döneminde turizm. (123-145), Adnan Akın (Ed.), Spesifik Akademik Araştırmalar IKSAD Publications.

Akın, A. (2018a). Turist rehberlerinin mesleki örgütlenmelerinin değerlendirilmesi, Güncel Turizm Araştırmaları, Aliye Akın (Ed.), (98-155), IKSAD Publications. 
Akın, A. (2018b). Turizm potansiyelinin değerlendirilmesi (Gaziantep örneği). Aliye Akın (Ed.), Güncel Turizm Araştırmaları, (8-63), IKSAD Publications.

Akın, A. (2020b). Türkiye'de turizmin gelişimi: engeller ve firsatlar, Enver Günay (Ed.), Türkiye'nin Yakın Dönem İktisadi Tarihi ve Sosyo Ekonomik Sorunları, (1312-157), Gece Kitaplığı.

Akıncı, Z. \& Yüzbaşığlu, N. (2015). Türkiye, dünya turizm sektörü içerisinde bir belirleyici mi, yoksa bir taşı1ıı mı? Finans Politik \& Ekonomik Yorumlar Dergisi, 52(609), 45-61.

Bacaklığlu, G. (2017). Büyük Ölçekli Konaklama İşletmelerinde Risk Yönetimi Algısı. (Yüksek Lisans Tezi), Muğla S1tkı Koçman Üniversitesi, Sosyal Bilimler Enstitüsü, Muğla.

Çetin, E. (2018). 19. Yüzyılın ikinci yarısında Osmanlı Devleti'nde otel ve misafirhanelere dair düzenlemeler. Anatolia: Turizm Araştırmaları Dergisi, 29 (1), 63 - 76.

Çımat, A. \& Bahar, O. (2003). Turizm sektörünün Türkiye ekonomisi içindeki yeri ve önemi üzerine bir değerlendirme. Akdeniz İ.İ.B.F. Dergisi, 6, 1-18.

Dinçer, M. Z. \& Çetin, G. (2015). Kalkınma planlarında turizm. D. Küçükaltan, H. Çeken \& O. Mercan (Eds.), Değişik Perspektifleriyle Turizm Politikası ve Planlaması, Detay Yayınc1lık, Ankara.

Erkmen, A. \& Akın, A. (2018). Siyasi partilerin 2018 genel seçim beyannamelerindeki turizm vaatlerinin turizm stratejisi 2023 kapsamında değerlendirilmesi. Aliye Akın ( Ed.), Güncel Turizm Araştırmaları (199-246). IKSAD Publications.

Erkmen, A. (2019). Uluslararası turizmin tarihi gelişim süreci. Aliye Akın (Ed.), Uluslararası Turizm Uygulamaları, (3-34). IKSAD Publications.

Ertürk, E. (2001). Kalkınma için bölgesel işbirliği teşkilatı. TDV İslam Ansiklopedisi, 24. Cilt, İstanbul.

Köseoğlu, A. (2019). Hüzün Turizmi Kapsamında Çanakkale Savaşlarının Turizm Ekonomisine Etkisi. (Yüksek Lisans Tezi), Selçuk Üniversitesi Sosyal Bilimler Enstitüsü, Konya.

Öner, O. (1974). Türkiye’yi uluslararası ekonomik kuruluşlara üye yapan antlaşmalar. Ankara Üniversitesi Siyasal Bilgiler Fakültesi Yayınları, No:376.

Özdemir, M. (2011).Türkiye'de Turizmin Başlaması: Osmanlı'da Sanayileşme Çabaları: Sergi-i Umum-i Osmanî (1863 İstanbul Uluslararası Sergisi). Anatolia: Turizm Araştırmaları Dergisi, 22( 1), 87-90.

Quresh. A. R.C.D. Yönetim potansiyelinin geliştirilmesi, Amme İdaresi Dergisi, https://silo.tips/download/rcd-ynetim-potansiyelinin-gelitirilmesi. (Erişim Tariihi: 08.10.2020).

Sandalcılar, A. R. (2010). Ekonomik İşbirliği Teşkilatı'nın Ticari Analizi-SITC Sınıflandırılması Ve Çekim Modeli Üzerine Bir Uygulama-, (Doktora Tezi), Atatürk Üniversitesi Sosyal Bilimler Enstitüsü İktisat Anabilim Dalı, Erzurum.

Sarı Çallı, D. (2015). Uluslararası seyahatlerin tarihi gelişimi ve son seyahat trendleri doğrultusunda Türkiye'nin konumu. Turizm ve Araştırma Dergisi, 4(1), 4-28. 
Soyu, E., Karaçor, S., Altınok, S. \& Firat, E. (2017). Türkiye'de turizm gelirlerinin ekonomideki yeri ve önemi üzerine bir değerlendirme. International Conference On Eurasian Economies.

Uçarol, R. (2006). Siyasi tarih (1789-2001). DER yayınları, İstanbul.

Vatan, A. (2018). Bilecik'in turizm destinasyonu olarak değerlendirilmesine yönelik yerel paydaş analizi. Journal ofTourism and Gastronomy Studies, 6 (4), 604-625.

Yeşilbursa, B. K. (2009). The formation of RCD: Regional Cooperation for Development. Middle Eastern Studies, 45(4), 637-660.

Yıldız, Z. (2011). Turizm sektörünün gelişimi ve istihdam üzerindeki etkisi. Süleyman Demirel Üniversitesi Vizyoner Dergisi, 3(5), 54-71. 